\title{
(ง)
}

UNIVERSIDAD PERUANA DE CIENCIAS APLICADAS

FACULTAD DE CIENCIAS DE LA SALUD

PROGRAMA ACADÉMICO DE MEDICINA

\section{FREQUENCY AND COINFECTION BETWEEN \\ GENOTYPES OF HUMAN PAPILLOMAVIRUS IN A \\ POPULATION OF ASYMPTOMATIC WOMEN IN NORTHERN PERU}

FRECUENCIA Y COINFECCION ENTRE GENOTIPOS DEL VIRUS DEL PAPILOMA HUMANO EN UNA POBLACION DE MUJERES ASINTOMATICAS EN EL NORTE DEL PERU

TRABAJO DE SUFICIENCIA PROFESIONAL PARA OPTAR EL TITULO DE MEDICO CIRUJANO

AUTORES

PONCE BENAVENTE, LUIS ALBERTO (0000-0001-5792-2143)

REJAS PINELO, PATRICIA ANDREA (0000-0002-9785-3573)

ASESORES

JUANA DEL VALLE MENDOZA (0000-0002-6011-5040)

MIGUEL ANGEL AGUILAR LUIS (0000-0001-7023-3190)

Chorillos 21 de Septiembre del 2018 
A nuestros padres, hermanos y abuelos 
Acknowledgment

A nuestros padres y hermanos por su gran apoyo y preocupación durante el desarrollo del manuscrito. A papito Juan, Oscar y mamita Carmela, Teresa y María Santos porque sin ellos no seriamos lo que somos ahora. A H Cook por su apoyo para continuar con el trabajo diario. A Aaron, Can, Morenuca y Luna por su compañía incondicional durante todo el proceso. A nuestros asesores por la guía constante para llegar a la meta. 


\begin{abstract}
Objective: Describe the prevalence of HPV genotypes via PCR and DNA sequencing in 397 women who attended to the gynecological outpatient clinic in the Hospital Regional Docente de Cajamarca from March to September 2017. Methods and materials: The samples from the endocervix and ectocervix were stored and then we proceeded to do detection with genotyping, high and low risk types, by PCR. Results: A positive PCR result for HPV was observed in 121 cervical samples. A high-risk genotype was found in $63.6 \%(77 / 121)$ of patients, a probably oncogenic type in $23.1 \%(28 / 121)$ and a low-risk type in 7.4\%. Among the high-risk genotypes, HPV-31 was the most common one present in $20 \%(21 / 77)$, followed by HPV-16 in $11.4 \%(12 / 77)$. Coinfections between two or more genotypes were observed in 12 cases. KEYWORDS: HPV, Cervical cancer, PCR, Peru
\end{abstract}

Objetivo: Describir la prevalencia de genotipos del VPH con PCR y secuenciación del ADN en 397 mujeres que acudieron a consulta externa del Hospital Regional Docente de Cajamarca desde Marzo hasta Septiembre del 2017. Materiales y métodos: las muestras del endocérvix y ectocérvix fueron almacenadas y luego se procedió a la detección de tipos del alto y bajo riesgo con PCR. Resultados: un PCR positivo para VPH se observó en 121 muestras cervicales. Se encontró 63.6\% (77/121) de genotipos de alto riesgo, $23.1 \%$ (28/121) genotipos probablemente oncogénicos y 7.4\% genotipos de bajo riesgo. De los genotipos de alto riesgo, VPH-31 fue el más común en un 20\% (21/77), seguido de VPH-16 en un 11.4\% (12/77). Coinfección entre dos o más genotipos se observó en 12 casos.

Palabras clave: HPV, cervical cancer, PCR, Peru. 
Table of content

INTRODUCTION ....................................................................... 7

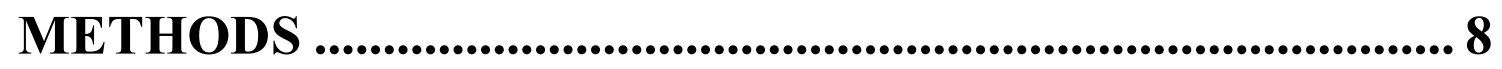

PATIENTS AND STUDY DESIGN............................................. 8

SAMPLE COLLECTION AND PRESERVATION ................................ 8

HPV DNA EXTRACTION, AMPLIFICATION AND GENOTYPE

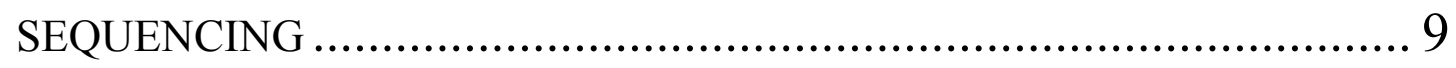

STATISTICAL ANALYSIS .................................................... 9

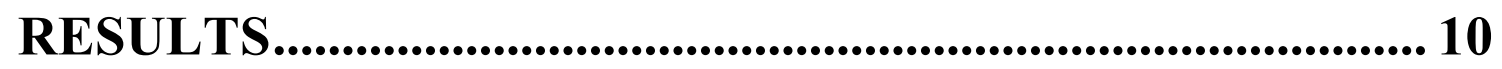

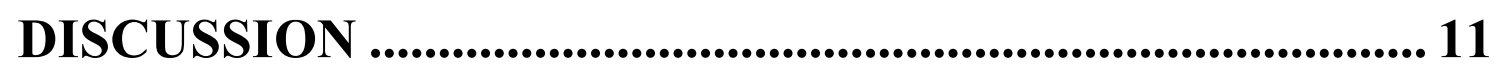

CONCLUSION ............................................................................... 13 


\section{Tables}

Table 1 Human papillomavirus infection in women from Cajamarca, Peru .................. 16

Table 2 Prevalence of HPV genotypes detected in women from Cajamarca, Peru........ 17

Table 3 Demographics and characteristics among women with HPV ......................... 18

Table S1 Human papillomavirus types and oncogenic potential ................................ 20 


\section{Introduction}

Cervical cancer is the second leading cause of female cancer mortality in Peru accounting for more than 1700 deaths annually [1]. Human papillomavirus (HPV) is the main responsible for this cancer and one of the most common sexually transmitted infection in Peru $[2,3]$. HPV is a DNA virus from the papillomavirus family with over 170 types completely sequenced. Although the association between these genotypes and their risk of malignancy varies, its presence in $99.7 \%$ of cervical cancers has been recognized as core to the development of this neoplasia [4, 5]. HPV genotypes identified in women with cervical cancer are traditionally classified based on their associated risk of malignancy $[5,6]$. Thus, 13 genotypes have been classified as "high risk" as they are detected in more than $90 \%$ of women with cervical cancer, with HPV 16 accounting for approximately $50 \%$ of cases, followed by HPV 18 in 20\% [6-9]. Furthermore, in 2009 the International Agency for Research on Cancer (IARC) further classified other 12 genotypes as "probably oncogenic" and 2 as "low risk" based on their limited evidence in humans for cervical cancer [9]. After over 30 years of screening services and with cervical cancer declared a national priority in 2000, HPV infections remains a major concern in Peru especially affecting underserved areas where surveillance is limited [3, 10-12]. The main objective of this study was to describe the prevalence of the HPV oncogenic genotypes among women from Cajamarca, Peru as well as to provide preliminary reports of their potential risk factors. 


\section{Methods}

\section{Patients and study design}

A consecutive cross-sectional study was conducted in the Hospital Regional Docente de Cajamarca, Peru. Women attending the gynecological outpatient center who had a history of at least 1 sexual encounter were studied from March to September 2017. Patients were excluded if there was evidence of pregnancy, severe gynecological bleeding, hysterectomy or previous history of HPV-related disease including cancer, warts and other cutaneous manifestations. This study has been approved by two independent Ethics Committees: Hospital Regional Docente de Cajamarca and Universidad Peruana de Ciencias Aplicadas. Once the outpatient consultation ended, the attending physicians informed the patients about the study purpose and asked for written consent before enrollment. After a standardized questionnaire was completed by the physician a cervical sample was collected for further analysis. The questionnaire includes the following data: age, marital status, age of first sexual intercourse, number of sexual partners, sexual partners in the last 6 months, extramarital sexual relations, history of sexually transmitted infection (STI), abortions, Number of births, use of condoms, last pap, personal and family history of cervical cancer, use of sex toys, history of sexual abuse and date of the last Papanicolaou test.

\section{Sample collection and preservation}

Cervical cell samples from the ectocervix and endocervix were collected from each woman using a cytobrush for preservation in a tube containing phosphate buffered saline $\left(\mathrm{pH}\right.$ 8.6). The samples were then stored at $-4^{\circ} \mathrm{C}$ and sent to the Molecular Biology Laboratory at Universidad Peruana de Ciencias Aplicadas. Once samples arrived at the laboratory, the cytobrushes were discarded and the tubes were vortexed and centrifuged to pellet the cells, which were resuspended in $1 \mathrm{~mL}$ of phosphate buffered saline. Three aliquots of each fresh specimen were stored at $-20^{\circ} \mathrm{C}$ until testing. 


\section{HPV DNA extraction, amplification and genotype sequencing}

Viral genomic DNA was extracted from a total volume of $200 \mu \mathrm{L}$ of the sample by the guanidinium thiocyanate extraction method [13] and the purified material was resuspended in a final volume of $30 \mu \mathrm{L}$ deionized water. Samples were electrophoresed on a $1 \%$ agarose gel to check the quality of the DNA. Human papillomavirus amplification was done using the primers and conditions described by Lurchachaiwong et al. [14]. PCR products were analyzed on 2\% agarose gel stained with. Ethidium bromide and bands were detected by UV transillumination (Kodack Logic 1500, USA). Positive specimens were confirmed by direct sequencing serving as the gold standard (Macrogen-Korea). The HPV genotypes were categorized into three groups: high, probably oncogenic and low risk based on the IARC classification [9] (Additional file 1: Table S1).

\section{Statistical analysis}

Quantitative variables were described as frequencies and percentages for each group using the GraphPad Prism3statistical (Graph Pad Sofware Inc., San Diego, USA). 


\section{Results}

A total of 397 women were studied from March to September 2017. Most patients were between 36 and 45 years old (35\%) followed closely by the age group 26-35 years old (30.2\%); 51 patients were under 25 years old (12.8\%) with only two patients under 18 years old (Table 1). Human papillomavirus DNA was amplified in 121 of our patient's samples and all of them were successfully sequenced for genotype identification. A highrisk genotype was found in $63.6 \%(77 / 121)$ of patients, a probably oncogenic type in $23.1 \%(28 / 121)$ and a low-risk type in $7.4 \%$; other genotypes were detected in $19.83 \%$. All sequenced genotypes are shown in Table 2. Coinfections between two or more genotypes were observed in 12 cases. The most common coinfections were between HPV types 39-45-68, 40-43-91 and 31-91 each of them in two cases (Additional file 1:Table S2). Demographic and other potential risk factors for HPV infections were also registered from each patient. Most women were married/cohabiting, had one sexual partner, maintaining sexual relationships in the last 6 months. However, only $35.5 \%$ of them uses condoms and the use of sex toys was uncommon. Extramarital affairs were observed in $3.3 \%$ of patients and there were 31 cases with a history of sexual abuse. Most patients were multiparous with three or more births (36.8\%) (Table 3). Among women who were infected by a high-risk HPV genotype, similar characteristics were observed with certain exceptions. In this group, it was slightly more common to observe 2-lifetime sexual partners and the majority were sexually active (82.1\%). Although uncommon, 53.8\% of extramarital affairs were observed in this group. Additionally, 19 of these women have never had a Pap smear test for cervical cancer screening (Table 3). 


\section{Discussion}

Cervical cancer is the most common female cancer in Peruvian women between 15 and 44 years-old, with about 4700 new cases diagnosed annually and an estimated mortality of 24.6 per 100,000 women [3,10]. There is clear evidence that HPV is the main responsible for cervical cancer and prevalence studies of the oncogenic genotypes are encourage especially in low-income communities were surveillance reports are still limited [3, 10-12, 15]. In our study population of 397 women, a total of 121 samples were positive for HPV via PCR, with a high-risk genotype present in 77 samples and a probably oncogenic genotype in 28 . In the high-risk group, the most common genotypes were HPV-31 (20\%) followed by HPV-16 (11.4\%). These results differ from a previous investigation our research team conducted in Cajamarca between 2010 and 2012, in which the HPV-16 was the most common genotype in 38.5\%, followed by the HPV-39 in $9.6 \%$ [15]. Another investigation in 465 women, without the diagnosis of cervical cancer, from Lima, Peru reported the genotypes HPV-16 (23.8\%) and HPV-6 (11.9\%) [16] as the most common ones. Furthermore, a study conducted in an Amazonian region of Peru showed a higher frequency of high-risk HPV among females from an urban population in Iquitos compared to a native Amazonian population. However, the genotypes distribution in both population were different. In the urban population, HPV-16 was the most common type in 58.5\% followed by HPV-18 and HPV-31. On the contrary, in the Amazonian native community, HPV-16 was uncommon, as other unique HPV types were more frequently observed in these patients such as HPV-39, HPV-71, and HPV-96 [17]. Thus, HPV genotypes distribution can widely vary between two different close regions from the same country and changes in genotype prevalence are expected, with studies reporting an HPV16 prevalence significant decrease in the last years after the introduction of the vaccine [18-20]. Multiple genotypes can be detected in patients with cervical cancer suggesting that coinfections might be a potential risk factor for carcinogenesis. A recently published study from 2017, reported a 4.1-fold higher risk of developing invasive cervical carcinoma in subjects infected with any HPV genotype, excluding HPV-16, in association with HPV-18 [21]. Thus, the risk of cervical cancer is genotype specific, but it might be increased with certain genotype interactions. In our study, only one case of HPV-16 coinfection was observed, but coinfections with a high-risk type occurred in 5 samples, 
including a triple coinfection between HPV-39, HPV-45, and HPV-68. Genital HPV infections are spread by unprotected penetrative intercourse or close skin-to-skin physician contact $[22,23]$. In our population, most patients did not use condoms $(64.5 \%)$, and this increased risk practice was observed in all our HPV-positive patients (56.2\%), high-risk HPV positive (54.5\%) and probably oncogenic HPV positive women (57.1\%). Fomite contact or vaginally inserted sex toys can potentially spread HPV as the virus can be detected up to $24 \mathrm{~h}$ after standard cleaning, but the evidence is not definitive. The use of sexual toys was very uncommon in our patients $(2 \%)$, with a positive HPV sample in 4 of the 8 cases. The risk of HPV infection in women is directly related to the number of male sex partners. Furthermore, as with other sexually transmitted diseases, sex with a new partner is a stronger risk factor than sex with long-term partners [24-28]. In our study, females with 3 or more partners represented $25.6 \%$ of HPV-positive patients. Additionally, 4 cases of HPV were observed in females who had 2 or more partners in the last 6 months; although most of our patients with HPV (80.2\%) were sexually active with 1 partner in the last 6 months. Similar results were observed in our previous investigation in which the groups of women with a history of 2 sexual partners and the group with 3 or more partners represented $25 \%$ and $17.3 \%$ of the total HPV positive cases [15]. In 2011, Almonte et al. conducted a research in women attending cervical cancer screening in the Peruvian Amazon. In this study, early age at first sexual intercourse and more than 5 sexual partners were risk factors for having HPV infection. More interestingly, high parity, no schooling and the lack of a good-quality screening with an adequate follow-up were the main risk factors for high-grade cervical disease [29]. Even though, assessing a risk for cervical disease was not part of our objectives, we observed that $36.8 \%$ of our population had 3 or more births and a similar tendency was reported among HPV positive women. Human papillomavirus DNA testing is increasingly being used as it improves the sensitivity for detection of cervical cancer precursors when used in combination with cervical cytology. However, using molecular testing can also decrease specificity resulting in potential unnecessary referrals for colposcopy [30]. Additionally, HPV PCR is not recommended in women under 30 years old since the HPV may clear up spontaneously in younger women [31, 32]. Thus, the Papanicolaou test is recommended as the first screening method with a co-testing HPV PCR only in women $\geq 30$ years old. In our population, 24.7\% (19/77) of our HPV high- risk group never had a pap smear; however, most of these women (73.7\%) were under 30 years old. 


\section{Conclusion}

Despite national efforts for cervical cancer screening and prevention, HPV infections resulting in invasive cervical cancer remains a major health issue in Peru. Additionally, in underserved areas such as Cajamarca HPV genotype surveillance is limited. Contrary to previous reports in which HPV-16 was predominant, an increase of HPV-31 have been observed which is now the most common high-risk genotype in our study population.

\section{References}

1. Aguilar A, Pinto J, Araujo J, Fajardo W, Bravo L, Pinillos L, et al. Control of cervical cancer in Peru: current barriers and challenges for the future. MolClin Oncol. 2016;5(2):241-5.

2. Santos C, Munoz N, Klug S, Almonte M, Guerrero I, Alvarez M, et al.HPV types and cofactors causing cervical cancer in Peru. Br J Cancer. 2001;85(7):96671.

3. Bruni L, Barrionuevo-Rosas L, Albero G, Serrano B, Mena M, Gómez D, et al. ICO/IARC information centre on HPV and cancer (HPV information centre). Human papillomavirus and related diseases in Peru. Summary Report 27 July 2017. http://www.hpvce ntre.net/stati stics /repor ts/PER.pdf. Accessed 27 July 2017.

4. Walboomers J, Jacobs M, Manos M, Bosch F, Kummer J, Shah K, et al. Human papillomavirus is a necessary cause of invasive cervical cancer worldwide. J Pathol. 1999;189(1):12.

5. Senapati R, Nayak B, Kar S, Dwibedi B. HPV genotypes co-infections associated with cervical carcinoma: special focus on phylogenetically related and non-vaccine targeted genotypes. PLoS ONE. 2017;12(11):e0187844. 6. Jentschke M, Soergel P, Hillemanns P. Importance of HPV genotyping for the screening, therapy and management of cervical neoplasias. Geburtshilfe Frauenheilkd. 2012;72(6):507-12.

7. Bernard E, Pons-Salort M, Fayre M, Heard I, Delaqocque-Asagneau E, Didier $\mathrm{G}$, et al. Comparing human papillomavirus prevalences in women with normal cytology or invasive cervical cancer to rank genotypes according to their 
oncogenic potential: a meta-analysis of observational studies. BMC Infect Dis. $2013 ; 13: 373$.

8. Muñoz N, Bosch F, de SanJose S, Herrero R, Castellsague X, Shah K, et al. Epidemiologic classification of human papillomavirus types associated with cervical cancer. N Engl J Med. 2003;348(6):518-27. 9. Bouvard V, Baan R, Straif K, Grosse Y, Secretan B, El Ghissassi F, et al. A review of human carcinogens-Part B: biological agents. Lancet Oncol. 2009;10(4):321-2.

10. Pan American Health Organization (PAHO). Cervical cancer prevention in Peru: lessons learned from the TATI demonstration project. Washington, D.C. [Cited on May 26, 2018]. https ://www.paho.org/hq/index .php?option $=$ com_conte $n t \& v i e w=$ artic le\&id=5040\%3A201 1 -cervi cal-cance rprevention -peru-lesso ns-learn ed-from-tati-demon strat ion-proje ct\&catid=1872\%3Acan cer\&Itemi d=40602 \&lang=en. Accessed 22 May 2018. 11. Almonte M, Ferreccio C, Winkler J, Cuzick J, Tsu V, Robles S, et al. Cervical screening by visual inspection, HPV testing, liquid-based and conventional cytology in Amazonian Peru. Int J Cancer. 2007;121(4):796-802. 12. Levinson K, Abuelo C, Salmeron J, Chyung E, Zou J, Belison S, et al. The Peru Cervical Cancer Prevention Study (PERCAPS): the technology to make screening accessible. Gynecol Oncol. 2013;129(2):318-23. 13. Camps M, Vilella A, Marcos MA, Letang E, Muñoz J, Salvadó E, et al. Incidence of respiratory viruses among travelers with a febrilesyndrome returning from tropical and subtropical areas. J Med Virol. 2008;80(4):711-5. 14. Lurchachaiwong W, Junyangdikul P, Payungporn S, Sampatanukul P, Chansaenroj J, Tresukosol D, et al. Human papillomavirus genotypes among infected Thai women with different cytological findings by analysis of E1 genes. New Microbiol. 2011;34(2):147-56. 15. Silva-Caso W, Olivera-Irazabal M, Leon-Alvarez P, Del Valle LJ, DiazEstacio S, Vargas M, et al. Identification of human papillomavirus as a preventive strategy for cervical cancer in asymptomatic women in the Peruvian Andes. Asian Pac J Trop Med. 2014;7S1:S121-6. 16. Sullcahuaman-Allende Y, del Castro-Mujica MC, Mejia C, Castaneda C, Castillo M, Dolores-Cerna K, et al. Demographic characteristics of human 
papillomavirus detected by PCR-RFLP in peruvian women. Send to Rev Peru Med Exp Salud Publica. 2015;32(3):509-14 (Article in Spanish). 17. Martorell M, Garcia-Garcia J, Gomez-Cabrero D, Del Aguila A. Comparison of the prevalence and distribution of human papillomavirus infection and cervical lesions between urban and native habitants of an Amazonian region of Peru. Genet Mol Res. 2012;11(3):2099-106.

18. Dong L, Hu S, Zhang Q, Feng R, Zhang L, Zhao X, et al. Changes in genotype prevalence of human papillomavirus over 10-year follow-up of a cervical cancer screening cohort. Zhonghua Liu Xing Bing Xue Za Zhi. 2017;38(1):20-5. 19. Mesher D, Soldan K, Howell-Jones R, Panwar K, Manyenga P, Jit M, et al. Reduction in HPV 16/18 prevalence in sexually active young women following the introduction of HPV immunisation in England. Vaccine. 2013;32(1):26-32. 20. Mesher D, Panwar K, Thomas S, Beddows S, Soldan K. Continuing reductions in HPV 16/18 in a population with high coverage of bivalent HPV vaccination in England: an ongoing cross-sectional study. BMJ Open. 2016;6(2):e009915. 21. Senapati R, Nayak B, Kumar-Kar S, Dwibedi B. HPV genotypes co-infections associated with cervical carcinoma: special focus on phylogenetically related and non-vaccine targeted genotypes. PLoS ONE. 2017;12(11):e0187844. 22. Burchell A, Winer R, de SanJose S, Franco E. Chapter 6: Epidemiology and transmission dynamics of genital HPV infection. Vaccine. 2006; 24 Suppl3:S3/52-61.

23. Palefsky J. Cutaneous and genital HPV-associated lesions in HIV-infected $\begin{array}{llll}\text { patients. } & \text { Clin } & \text { Dermatol. }\end{array}$ 24. Anderson T, Schick V, Herbenick D, Dodge B, Fortenberry J. A study of human papillomavirus on vaginally inserted sex toys, before and after cleaning, among women who have sex with women and men. Sex Transm Infect. 2014;90(7):529-31.

25. Tarkowski T, Koumans E, Sawyer M, Pierce A, Black C, Papp J, et al. Epidemiology of human papillomavirus infection and abnormal cytologic test results in an urban adolescent population. J Infect Dis. 2004;189(1):46. 26. Peyton C, Gravitt P, Hunt W, Hundley R, Zhao M, Apple R, et al. Determinants of genital human papillomavirus detection in a US population. $J$ Infect

Dis. 2001;183(11):1554. 
27. Karlsson R, Jonsson M, Edlund K, Evander M, Gustavsson A, Bodén E, et al. Lifetime number of partners as the only independent risk factor for human papillomavirus infection: a population-based study. Sex Transm Dis. 1995;22(2):119.

28. Moscicki A, Hills N, Shiboski S, Powell K, Jay N, Hanson E, et al. Risks for incident human papillomavirus infection and low-grade squamous intraepithelial lesion development in young females. JAMA. 2001;285(23):2995. 29. Almonte M, Ferreccio C, Gonzales M, Delgado J, Buckley C, Luciani S, et al. Risk factors for high-risk human papillomavirus infection and cofactors for highgrade cervical disease in Peru. Int J Gynecol Cancer. 2011;21(9):1654-63. 30. Schiffman M, Wentzensen N, Wacholder S, Kinney W, Cage J, Castle P. Human papillomavirus testing in the prevention of cervical cancer. J Natl Cancer Inst. 2011;103(5):368-83.

31. Meijer C, Berkhof J, Castle P, Hesselink A, Franco E, Ronco G, et al. Guidelines for human papillomavirus DNA test requirements for primary cervical cancer screening in women of 30 years and older. Int J Cancer. 2009;124(3):51620.

32. Leinonen M, Nieminen P, Kotaniemi-Talonen L, Malila N, Tarkkanen J, Laurila P, et al. Age-specific evaluation of primary human papillomavirus screening vs conventional cytology in a randomized setting. Natl Cancer Inst. 2009;101(23):1612.

\section{Anexos}

Table 1 Human papillomavirus infection in women from Cajamarca, Peru

\begin{tabular}{|l|l|l|l|l|l|l|}
\hline \multirow{2}{*}{ Age } & \multirow{2}{*}{$\begin{array}{l}\text { TOTAL } \\
\mathrm{n}=\quad 397 \\
(\%)\end{array}$} & $\begin{array}{l}\text { HPV positives } \\
\mathrm{n}=121(\%)\end{array}$ & $\begin{array}{l}\text { High risk } \\
n=77(\%)\end{array}$ & $\begin{array}{l}\text { Probably } \\
\text { oncogenic } \\
\mathrm{n}=28(\%)\end{array}$ & $\begin{array}{l}\text { Low risk } \\
\mathrm{n}=9(\%)\end{array}$ & $\begin{array}{l}\text { Other } \\
\text { types* } \\
\mathrm{n}=24(\%)\end{array}$ \\
\hline$\leq 25$ & $51(12.8)$ & $22(18.2)$ & $16(20.8)$ & $4(14.3)$ & $2(22.2)$ & $3(12.5)$ \\
\hline $26-35$ & $120(30.2)$ & $43(35.5)$ & $30(38.9)$ & $9(32.1)$ & $3(33.3)$ & $7(29.2)$ \\
\hline $36-45$ & $139(35)$ & $41(33.9)$ & $23(29.9)$ & $12(42.9)$ & $4(44.5)$ & $8(33.3)$ \\
\hline$\geq 46$ & $87(21.9)$ & $15(12.4)$ & $8(10.4)$ & $3(10.7)$ & $0(0.0)$ & $6(25.0)$ \\
\hline
\end{tabular}


\begin{tabular}{|l|l|l|l|l|l|l|} 
Total & $\begin{array}{l}397 \\
(100.0)\end{array}$ & $121(100.0)$ & $77(100.0)$ & $28(100)$ & $9(100.0)$ & $24(100.0)$ \\
\hline
\end{tabular}

*Other HPV types: 9, 40, 42, 43, 44, 74, 90, 91, 96

Table 2 Prevalence of HPV genotypes detected in women from Cajamarca, Peru

\begin{tabular}{|c|c|c|}
\hline \multicolumn{3}{|c|}{ HIGH RISK } \\
\hline Genotype & $\mathrm{n}=77$ & $(\%)$ \\
\hline HPV16 & 12 & 11.4 \\
\hline HPV18 & 1 & 1 \\
\hline HPV31 & 21 & 20 \\
\hline HPV33 & 3 & 2.9 \\
\hline HPV35 & 8 & 7.6 \\
\hline HPV39 & 2 & 1.9 \\
\hline HPV45 & 4 & 3.8 \\
\hline HPV51 & 4 & 3.8 \\
\hline HPV52 & 9 & 8.6 \\
\hline HPV56 & 5 & 4.8 \\
\hline HPV58 & 2 & 1.9 \\
\hline HPV59 & 1 & 1 \\
\hline HPV68 & 5 & 4.8 \\
\hline
\end{tabular}

PROBABLY ONCOGENIC

\begin{tabular}{|l|l|l|}
\hline Genotype & $\mathrm{n}=28$ & $\mathbf{( \% )}$ \\
\hline HPV26 & 1 & 1 \\
\hline HPV34 & 7 & 6.7 \\
\hline HPV53 & 2 & 1.9 \\
\hline HPV66 & 2 & 1.9 \\
\hline HPV69 & 5 & 4.8 \\
\hline HPV70 & 9 & 8.6 \\
\hline HPV73 & 2 & 1.9 \\
\hline LOW RISK & \multicolumn{2}{|l}{} \\
\hline Genotype & $\mathrm{n}=9$ & $\mathbf{( \% )}$ \\
\hline HPV6 & 8 & 88.9 \\
\hline
\end{tabular}




\begin{tabular}{|l|l|l|}
$\mid$ HPV11 & 1 & 11.1 \\
\hline OTHER HPV TYPES & $\mathrm{n}=24$ & $\mathbf{( \% )}$ \\
\hline Genotype & 1 & 4.2 \\
\hline HPV9 & 2 & 8.3 \\
\hline HPV40 & 2 & 8.3 \\
\hline HPV42 & 2 & 8.3 \\
\hline HPV43 & 1 & 4.2 \\
\hline HPV44 & 2 & 8.3 \\
\hline HPV74 & 9 & 37.5 \\
\hline HPV90 & 4 & 16.7 \\
\hline HPV91 & 1 & 4.2 \\
\hline HPV96 & &
\end{tabular}

Table 3 Demographics and characteristics among women with HPV

\begin{tabular}{|c|c|c|c|c|c|c|}
\hline \multirow[b]{2}{*}{ Characteristics } & \multirow[b]{2}{*}{$\begin{array}{l}\text { TOTAL } \\
\text { n }=397 \\
(\%)\end{array}$} & \multirow[b]{2}{*}{$\begin{array}{l}\text { HPV } \\
\text { positives } \\
n=121 \\
(\%)\end{array}$} & \multicolumn{4}{|c|}{ HPV types detected } \\
\hline & & & $\begin{array}{l}\text { High } \\
\text { risk } \\
\text { n }=77 \\
(\%)\end{array}$ & $\begin{array}{l}\text { Probably } \\
\text { oncogenic } \\
n=28 \\
(\%)\end{array}$ & $\begin{array}{l}\text { Low } \\
\text { risk } \\
\text { n }=9 \\
(\%)\end{array}$ & $\begin{array}{l}\text { Other } \\
\text { HPV types } \\
\text { n=24(\%) }\end{array}$ \\
\hline \multicolumn{7}{|l|}{ Marital status } \\
\hline Married/cohabiting & $281(70.8)$ & $76(62.8)$ & $47(61.0)$ & $21(75.0)$ & $4(44.4)$ & $13(54.2)$ \\
\hline $\begin{array}{l}\text { Single/separated/ } \\
\text { divorced/widowed }\end{array}$ & $116(29.2)$ & $45(37.2)$ & $30(39.0)$ & $7(25.0)$ & $5(55.6)$ & $11(45.8)$ \\
\hline \multicolumn{7}{|c|}{$\begin{array}{l}\text { Lifetime number of sexual } \\
\text { partners }\end{array}$} \\
\hline 1 & $213(53.7)$ & $51(42.1)$ & $28(36.4)$ & $12(42.9)$ & $3(33.3)$ & $16(66.7)$ \\
\hline 2 & $114(28.7)$ & $39(32.2)$ & $23(29.9)$ & $13(46.4)$ & $2(22.2)$ & $6(25.0)$ \\
\hline$\geq 3$ & $69(17.4)$ & $31(25.6)$ & $26(33.8)$ & $3(10.7)$ & $4(44.4)$ & $2(8.3)$ \\
\hline \multicolumn{7}{|c|}{$\begin{array}{l}\text { Number of sexual partners } \\
\text { in the last } 6 \text { months }\end{array}$} \\
\hline 0 & $55(13.9)$ & $20(16.5)$ & $12(15.6)$ & $4(14.3)$ & $3(33.3)$ & $3(12.5)$ \\
\hline
\end{tabular}




\begin{tabular}{|c|c|c|c|c|c|c|}
\hline 1 & $336(84.6)$ & $97(80.2)$ & $62(80.5)$ & $23(82.1)$ & $6(66.7)$ & $21(87.5)$ \\
\hline$\geq 2$ & $6(1.5)$ & $4(3.3)$ & $3(3.9)$ & $1(3.6)$ & & \\
\hline \multicolumn{7}{|c|}{ Use of condom } \\
\hline Yes & $141(35.5)$ & $53(43.8)$ & $35(45.5)$ & $12(42.9)$ & $2(22.2)$ & $10(41.7)$ \\
\hline No & $256(64.5)$ & $68(56.2)$ & $42(54.5)$ & $16(57.1)$ & $7(77.8)$ & $14(58.3)$ \\
\hline \multicolumn{7}{|c|}{ Use of sex toys } \\
\hline Yes & $8(2.0)$ & $4(3.3)$ & $2(2.6)$ & $1(3.6)$ & - & $3(12.5)$ \\
\hline No & $389(98.0)$ & $117(96.7)$ & $75(97.4)$ & $27(96.4)$ & $9(100.0)$ & $21(87.5)$ \\
\hline \multicolumn{7}{|c|}{ Extramarital affairs } \\
\hline Yes & $13(3.3)$ & $6(5.0)$ & $7(9.1)$ & $1(3.6)$ & - & - \\
\hline No & $384(96.7)$ & $115(95.0)$ & $70(90.9)$ & $27(96.4)$ & $9(100.0)$ & $24(100.0)$ \\
\hline \multicolumn{7}{|c|}{ Victim of Sexual Abuse } \\
\hline Yes & $31(7.8)$ & $12(9.9)$ & $8(10.4)$ & $4(14.3)$ & - & $1(4.2)$ \\
\hline No & $366(92.2)$ & $109(90.1)$ & $69(89.6)$ & $24(85.7)$ & $9(100.0)$ & $23(95.8)$ \\
\hline \multicolumn{7}{|c|}{$\begin{array}{l}\text { Date of the Last } \\
\text { Papanicolaou test }\end{array}$} \\
\hline Never & $69(17.4)$ & $24(19.8)$ & $19(24.7)$ & $6(21.4)$ & - & $7(29.2)$ \\
\hline$\leq 1$ year & $199(50.1)$ & $59(48.8)$ & $40(51.9)$ & $12(42.9)$ & $5(55.6)$ & $9(37.5)$ \\
\hline$\geq 2$ years & $129(32.5)$ & $38(31.4)$ & $18(23.4)$ & $10(35.7)$ & $4(44.4)$ & $8(33.3)$ \\
\hline \multicolumn{7}{|c|}{ Number of births } \\
\hline 0 & $58(14.6)$ & $28(23.1)$ & $20(26)$ & $3(10.7)$ & $3(33.3)$ & $6(25.0)$ \\
\hline 1 & $90(22.7)$ & $34(28.1)$ & $21(27.3)$ & $9(32.1)$ & $1(11.1)$ & $11(45.8)$ \\
\hline 2 & $103(25.9)$ & $29(24)$ & $16(20.8)$ & $8(28.6)$ & $2(22.2)$ & $4(16.7)$ \\
\hline$\geq 3$ & $146(36.8)$ & $30(24.8)$ & $20(26)$ & $8(28.5)$ & $3(33.3)$ & $3(12.5)$ \\
\hline \multicolumn{7}{|c|}{ Number of abortions } \\
\hline 0 & $281(70.8)$ & $89(73.6)$ & $59(76.6)$ & $18(64.3)$ & $7(77.8)$ & $20(83.4)$ \\
\hline 1 & $86(21.7)$ & $21(17.4)$ & $12(15.6)$ & $6(21.4)$ & $2(22.2)$ & $2(8.3)$ \\
\hline 2 & $23(5.8)$ & $8(6.6)$ & $4(5.2)$ & $3(10.7)$ & - & $2(8.3)$ \\
\hline 3 & $7(1.8)$ & $3(2.5)$ & $2(2.6)$ & $1(3.6)$ & - & - \\
\hline
\end{tabular}

* HPV: Human papillomavirus 
Table S1 Human papillomavirus types and oncogenic potential

\begin{tabular}{|l|l|}
\hline IARC Classification & HPV types \\
\hline High risk (group 1/2A) & $\mathbf{a}$ \\
\hline Probably oncogenic (group 2B) & $16,18,31,33,35,39,45,51,52,56,58,59,68$ \\
\hline Low risk & $26,30,34,53,66,67,69,70,73,82,85,97$ \\
\hline
\end{tabular}

$\mathrm{HPV}=$ human papillomavirus.

a. Sufficient evidence for cervical cancer

b. Limited evidence for cervical cancer and classified by phylogenetic analogy to HPV types $1 / 2 \mathrm{~A}$ 